\title{
Transdyscyplinarne związki prawoznawstwa z naukami o języku. Od języków formalnych do nurtu ,prawo i literatura”
}

\begin{abstract}
...ani forma, ani treść dyscypliny nie jest tworzona przez nią samą, ale staje się przejrzysta przez wzgląd na relacje (podobieństwa i różnicy) do innych dyscyplin, które same są relacyjnie, nieesencjalnie, ukonstytuowane.
\end{abstract}

Stanley Fish

\section{Wprowadzenie}

Badanie językowego aspektu prawa pozostaje w oczywistym związku z integracją zewnętrzną prawoznawstwa, jak też wielopłaszczyznową koncepcją prawa, która nadal jest wielce inspirująca dla analiz interdyscyplinarnych. Istotnym założeniem jest przyjęcie kulturowego kontekstu języka prawnego. Płaszczyznę rozważań wyznaczają współczesne przekształcenia paradygmatu badania prawa $\mathrm{i}$ interpretacji prawniczej, będące m.in. następstwem tendencji ponowoczesnych i poststrukturalistycznych. Dominująca jest kwestia zakresu integracji prawoznawstwa z naukami o języku. Przedmiotem analizy będzie próba zweryfikowania, które $\mathrm{z}$ tych dyscyplin były przez teoretyków prawa wykorzystywane, a które mogłyby być do wykorzystania uwzględnione. Analiza koncentruje się wokół pytania o to, jak zmienia się zakres tej integracji w świetle współczesnych przekształceń w humanistyce i zmian w pojmowaniu prawa. Tekst ma na celu zaproponowanie do ewentualnego rozważenia postulatu zrewidowania koncepcji integracji zewnętrznej prawoznawstwa z dyscyplinami badającymi język oraz włączenia teorii literatury w zakres dyscyplin, $\mathrm{z}$ którymi prawoznawstwo jest zintegrowane.

${ }^{1}$ S. Fish, Profesjonalna poprawność. Badania literackie a polityczna zmiana, Poznań 2012, s. 76. 
Przedmiotem zainteresowania jest zatem integracja zewnętrzna prawoznawstwa z naukami badającymi tekst i język. Zgodnie z utrwaloną teoretycznoprawną intuicją, integracja prawoznawstwa w zakresie badania problemów językowych dotyczy nauk o języku². Oczywista wydaje się implikacja związków z takimi dyscyplinami, jak językoznawstwo ogólne, w tym semiotyka, pragmatyka czy stylistyka. Integracja dyscyplin, których obiektem badania jest język prawny, może przebiegać w dwóch kierunkach: na obszarze teorii prawa w nawiązaniu do metod językoznawczych oraz w obrębie lingwistyki w nawiązaniu do teorii prawa.

Teoretycy prawa wykazywali zainteresowanie językiem prawnym analizowanym w kontekście komunikacyjnym, głównie z uwzględnieniem perspektywy socjolingwistycznej. Inne ujęcia nawiązywały do teorii aktów mowy, semiotyki, jak też logiki i filozofii języka. Powiązania w ramach integracji zewnętrznej prawoznawstwa $\mathrm{z}$ naukami o języku, w tym głównie z lingwistyką, są ugruntowane $\mathrm{w}$ tradycji badawczej, natomiast analizy dotyczące integracji z teorią literatury pojawiają się zaledwie incydentalnie. Nie wydają się one dość powszechną tendencją, zwłaszcza w polskiej teorii prawa. Warto nadmienić, że zauważalne jest, iż badacze prawa wprawdzie sięgają do koncepcji przynależnych teorii literatury (np. Bachtina, Derridy czy Fisha), jednak integracja jest skoncentrowana głównie na metodach lingwistycznych.

Z kolei na gruncie lingwistyki język prawny był dotychczas badany w kontekście typologii odmian, wariantów stylowych oraz własności komunikacyjnych języka ogólnego. Dokonywane były także analizy z punktu widzenia genologii, teorii tekstu czy stylistyki. Eksplorowano kwestie odmian gatunkowych języka związanych ze sferą funkcjonowania prawa i administracji, takich jak np. teksty urzędowe i inne teksty związane z prawem (np. testament, teksty formułowane podczas rozprawy sądowej). Przedmiotem zainteresowania była charakterystyka terminologii języka prawnego, jak też badania diachroniczne nad językiem historycznych aktów prawnych. Poszczególne koncepcje lingwistyczne podejmowały analizy nad językiem w ogóle, przy czym nie odnosiły się one bezpośrednio do języka prawnego (poza wyjątkami na gruncie teorii aktów mowy, nurtów socjolingwistycznych i wywodzących się z nich ujęć języka prawnego jako odmiany zróżnicowanego języka ogólnego, czy też na gruncie stylistyki i pragmatystycznej teorii interpretacji).

Stan badań prowadzonych dotychczas w ramach teorii prawa i językoznawstwa pozwala spostrzec, iż pola badawcze obu dyscyplin są w pewnym zakresie zbieżne. Można wyodrębnić trzy główne obszary inspiracji. Pierwszy to traktowanie języka jako systemu, gdzie znajduje zastosowanie analiza strukturalno-semiotyczna oraz metody formalno-językowe. Drugi akcentuje

2 Nauki o języku rozumiane są tutaj szeroko - jako obejmujące badania nad problemami, które są istotne w płaszczyźnie językowej prawa (językiem, tekstem, znaczeniem, interpretacją). 
w badaniu języka wypowiedzi jako akty mowy i wykorzystuje dokonania pragmatyki językowej. Trzeci z kolei skupia się na badaniu języka stanowiącego tworzywo konstruowania tekstów postrzeganych jako obiekty znaczeniowe, sytuowane w kulturowym kontekście (a zatem na poziomie parole, a nie langue), gdzie skuteczne mogłyby być narzędzia wykorzystywane przez neopragmatyzm czy interpretacjonizm. Zauważalne jest, że współczesna teoria prawa wykorzystywała w analizowaniu języka prawnego głównie metodę systemowego badania języka oraz pochodzące z socjolingwistyki metody komunikacyjne. W dotychczasowych ujęciach stosowane były koncepcje zorientowane strukturalistyczno-semiotycznie. Należy zauważyć, iż użycie tych metod językoznawczych może być skuteczne w odniesieniu do pojęciowego wyodrębnienia i charakterystyki języka prawnego, specyfiki tekstu, komponentów komunikacji czy kwestii uwarunkowań socjolingwistycznych. Podkreślając produktywność zastosowania wymienionych metod w prawoznawstwie, można zauważyć, iż niewiele jest badań nawiązujących do koncepcji poststrukturalistycznych ${ }^{3}$. Oczywiste jest, że język (wraz z elementami wiedzy o faktach instytucjonalnych) jest zasadniczym otoczeniem i podstawą praktyki prawniczej. W związku z tym nie powinno się rezygnować z wykorzystywania metod badawczych tych dyscyplin, które się szczególnie nim interesują. Można zwrócić się nie tylko do tych nauk, których przedmiotem badania jest system językowy (lingwistyka), lecz także do tych, które badają tekst (teoria literatury). To właśnie teoria literatury jest dyscypliną, której centralnym obiektem zainteresowania jest tekst oraz rekonstruowanie jego treści na różnych poziomach.

Analiza dotychczasowego stanu badań w tym zakresie przekonuje, po pierwsze, o potrzebie uporządkowania analiz o charakterze interdyscyplinarnym, prowadzonych z perspektywy prawoznawstwa i językoznawstwa nad aspektem językowym prawa. Po drugie, zauważalna jest swoista niewystarczalność czy „nieadekwatność" językoznawstwa - nie tyle analizy strukturalno-semiotycznej, co integracji z językoznawstwem - w zakresie eksplorowania pewnych problemów specyficznych dla języka prawnego. Wykorzystanie metod lingwistyki przynosi rezultaty w zakresie badań funkcji języka prawnego, problemów stylistyki, genologii czy klasyfikacji na odmiany języka. Nie znajdują one natomiast skutecznego zastosowania do badania dyskursywnie rozumianej komunikacji czy interpretacji prawniczej, co oczywiście jest po części uzasadnione, ponieważ nie leży to w zasięgu zainteresowania tych dyscyplin. Warto zwrócić uwagę, że ani w językoznawstwie, ani w polskiej teorii literatury nie znajdujemy analiz bezpośrednio poświęconych kwestiom interpretacji tekstu prawnego.

3 Podobnie: S. Gajda, Prestiż w dyskursie prawnym, [w:] A. Choduń, S. Czepita (red.), W poszukiwaniu dobra wspólnego. Księga jubileuszowa Profesora Macieja Zielińskiego, Szczecin 2010, s. 820 . 


\section{Języki formalne versus teoria literatury}

Jak wskazano powyżej, w kwestii ewentualnego zastosowania w ramach integracji zewnętrznej prawoznawstwa narzędzi nauk o języku zauważalna jest pewna metodologiczna luka. Wynika to, być może, z faktu, że niektóre koncepcje lingwistyczne wykorzystywane przez teoretyków prawa znajdują ograniczone zastosowanie do badania języka prawnego jako odmiany języka naturalnego. Ich stosowalność nie jest bezproduktywna, ale ograniczona w odniesieniu do problemów semantyki. Dotyczy to np. koncepcji języków formalnych (jak w ujęciu Noama Chomsky’ego) stosowanych przez dyscypliny, których celem było poszukiwanie określoności, jednoznaczności w języku. Jak wiadomo, do czasu ukazania się Syntactis Structures (1957) językoznawcy w sposób odmienny od współczesnego pojmowali zadanie nauk o języku. Przedmiotem zainteresowania była przede wszystkim klasyfikacja składników języka z punktu widzenia ich morfologicznych właściwości. O ile tezy Chomsky’ego były w swoim czasie rewolucyjne i atrakcyjne dla przedstawicieli innych dyscyplin, to jednak znajdowały one zastosowanie głównie do badania języków sztucznych. Jak wiadomo, ich autorowi zawdzięcza się przełożenie idei skończonej procedury generatywnej właściwej dla nauk ścisłych na potrzeby językoznawstwa, co jest w jego koncepcji odkrywcze, zwłaszcza w zakresie dotyczącym badań nad „strukturą głęboką" języka. Wydaje się jednak, że próby stosowania metodologii nauk ścisłych mogą nie dawać zadowalających rezultatów w zakresie badania pragmatycznych i semantycznych problemów języka prawnego. Jak już powiedziano, koncepcje języków formalnych odnosiły się głównie (a zatem nie wyłącznie) do badania języków sztucznych, do których język prawny, rzecz jasna, nie przynależy. Przypomnijmy, że od czasu sformułowania koncepcji gramatyk generatywnych lingwistyka miała zacząć posługiwać się konstrukcjami teoretycznymi, które dotąd służyły do wyjaśniania zjawisk empirycznych, przy pominięciu wpływu intuicji i kontekstu ${ }^{4}$. Następnie, w wyniku ewoluowania procesów badawczych, zaczęto podejmować kwestie teoretycznego opisu języków naturalnych oraz problematykę komunikacji językowej. Język zaczął być postrzegany jako obiekt komunikacyjny, w odróżnieniu od badań nad językiem jako strukturą oderwaną od kontekstu (prowadzonych przez Ferdinanda de Saussure'a) czy systemem generatywnym (Noama Chomsky'ego). Jak wiadomo, również sam Chomsky ewoluował w swoich poglądach na język, przechodząc od analiz dotyczących gramatyk generatywnych w kierunku sformułowania Programu Minimalistycznego ${ }^{5}$. Przełom w lingwistyce (któremu towarzyszył też przełom w teorii prawa), jakim

4 B. Stanosz (red.), Język w świetle nauki, Warszawa 1980, s. 15.

5 Zob. np. N. Chomsky, The Minimalist Program, Cambridge 1995; idem, The Minimalist Program for Linguistic Theory, [w:] K. Hale, S. J. Keyser (eds), The View from Building 20, Cambridge 1993, s. 1-52. 
było odkrycie teorii aktów mowy i odejście od rozróżnień kartezjańskich (abstrahujących od kontekstu) w kierunku kontekstowości, przekształcił obraz językoznawstwa, języka i jego badania (również przez teoretyków prawa) w kierunku akcentowania roli kontekstu. Wywarło to istotny wpływ na współczesną humanistykę, o czym dobitnie świadczą tzw. zwroty (zwłaszcza zwrot kulturowy), które zaakcentowały problem kontekstu, a także (o czym dalej) spowodowały otwieranie się granic dyscyplin naukowych. Wpłynęło to także na badania na gruncie prawoznawstwa. Koncepcja Chomsky'ego czy gramatyki formalne są zatem nie tyle niestosowalne, ile mogą okazać się niewystarczające do analizy określonych skomplikowanych problemów semantyki i pragmatyki języka prawnego, które we współczesnych badaniach prawoznawczych zyskują na znaczeniu.

Metody badania języka proponowane przez twórców gramatyk formalnych, do których należy idea skończonej procedury generującej, znalazły skuteczne zastosowanie w badaniu języków sztucznych, zorientowanym głównie na problemy syntaktyki języka. Wiadome jest, że w analizach językowych w prawoznawstwie znaczną rolę pełni aspekt nie tylko syntaktyczny, lecz także semantyczny i pragmatyczny języka. W analizach teoretycznoprawnych kwestie analiz językowych wydają się użyteczne przede wszystkim w odniesieniu do problematyki tworzenia, stosowania oraz interpretacji prawa. Jak się wydaje, ani język nauk dedukcyjnych, ani językoznawstwo stosowane nie dadzą teoretykowi prawa satysfakcjonującej odpowiedzi w kwestii złożoności semantycznych problemów języka prawnego czy specyfiki jego interpretacji. Strukturalno-semiotyczne czy formalistyczne podejście wydaje się niewystarczająco produktywne w świetle zmian, jakie zaszły w humanistyce, a także teorii prawa po dokonaniu kulturowego $\mathrm{i}$ interpretacyjnego zwrotu, jak również ze względu na fakt, iż aktualnie kluczowym zagadnieniem z zakresu językowych analiz prawa jest kwestia interpretacji.

Zasięg stosowalności narzędzi dyscyplin stricte lingwistycznych do badania problematyki języka prawnego jest zatem ekstensjonalnie ograniczony. Przekonanie to koresponduje po części ze spostrzeżeniem Artura Kozaka, negatywnie weryfikującym wystarczalność czy stosowalność metod językoznawczych w prawoznawstwie. Zauważał on swoistą nieadekwatność lingwistyki w zakresie analizy specyficznych problemów językowych prawa, stwierdzając, że ,perspektywy prawoznawstwa i lingwistyki wydają się nieprzekładalne na siebie nawzajem" ${ }^{\circ}$. Wynika to z faktu, iż wprawdzie przedmiot badania jest wspólny, jednak istnieją rozbieżności w pojmowaniu problemów języka prawnego przez lingwistów i prawoznawców. Artur Kozak podaje przykłady ilustrujące fakt, że językoznawcy nie są w stanie zrozumieć, iż tekst prawny to nie jest gatunek tekstu w takim sensie, jak pojmuje to genologia, zaś o jego statusie decydują inne niż językowe wyznaczniki. Podobnie, jak zauważył cytowany autor, metody językoznawcze nie

${ }^{6}$ A. Kozak, Kulturowy fundament decyzji interpretacyjnej, [w:] A. Sulikowski (red.), Z zagadnień teorii i filozofii prawa. W poszukiwaniu podstaw prawa, Wrocław 2006, s. 45-46. 
są w stanie oddać specyfiki konstrukcji racjonalnego prawodawcy jako nadawcy tekstu prawnego. Oczywiście słuszne jest przekonanie, które wyraził Artur Kozak, iż język prawny jest specyficznym obiektem, zarówno w warstwie jego pojęciowego odróżnienia, jak i funkcji, swoistości tekstu, uczestników komunikacji itd. Zasadniczo należy zgodzić się z tym poglądem. Wydaje się jednak, że można zaproponować inną odpowiedź na tę „niewystarczalność” lingwistyki. Jeżeli pewne specyficzne aspekty języka prawnego nie dają się analizować za pomocą metod językoznawczych, to być może należy poszukiwać takich metod - interdyscyplinarnych, ponieważ obiektem badania jest tekst - które są w stanie uchwycić jego specyfikę. Warto sformułować postulat podjęcia badań nad językową stroną prawa przy zastosowaniu metod nie językoznawczych, lecz teoretycznoliterackich ${ }^{7}$. Badania językowych problemów prawoznawstwa nie ograniczają się bowiem do analiz wywodzących się z koncepcji analitycznych. W związku z tym pożądane może być poszukiwanie przez teoretyka prawa tych naukowych metod integracyjnych, które pozwolą na uchwycenie skomplikowanych problemów znaczenia i interpretacji tekstu prawnego, sytuowanych w ramach semantyki i pragmatyki. Przypuszczalnie odpowiedź na te fundamentalne z punktu widzenia współczesnych tendencji kwestie może dać nie lingwistyka, ale integracja $\mathrm{z}$ teorią literatury.

Objętość niniejszego szkicu uniemożliwia przedstawienie wszechstronnej argumentacji, warto jednak zasugerować taki postulat do ewentualnego rozważenia. Dla przykładu można posłużyć się odniesieniem chociażby do obecnych w teorii literatury koncepcji złożoności kategorii instancji nadawczej tekstu czy podmiotu czynności twórczej. Mogłyby tu znaleźć zastosowanie metody teoretycznoliterackie, np. polska strukturalistyczna szkoła teorii komunikacji i nieco zapomniana teoria odbioru dzieła literackiego. Uwzględniają one wielce istotny dla teoretyka prawa fakt, iż właściwy odbiór komunikatu językowego wymaga dokonania rozstrzygającej interpretacji z uwagi na to, że - jak pisze Aleksandra Okopień-Sławińska - „ostateczny i globalny sens wypowiedzi nigdy się [...] nie wyczerpuje w znaczeniach wprost w niej sformułowanych"8. Potwierdza to teze o wielopoziomowości tekstu prawnego i interpretowalności zawartych w nim treści, w tym także tych „zakodowanych” czy presuponowanych. Z kolei do analizy konstrukcji racjonalnego prawodawcy mogłyby być wykorzystane założenia koncepcji dwoistości ,ja” tekstowego i ,ja” twórcy. Przykładem włączenia metod teoretycznoliterackich do teorii prawa może być również aplikowanie założeń filozofii amerykańskiego neopragmatyzmu, reprezentowane w koncepcji

7 Zob. M. Andruszkiewicz, O zwiqzkach teorii prawa i teorii literatury (refleksje w kontekście tendencji ponowoczesnych), [w:] A. Samonek (red.), Teoria prawa między nowoczesnościa a ponowoczesnościq, Kraków 2012, s. 151-159.

8 A. Okopień-Sławińska, Semantyka ,,ja” literackiego (,, Ja” tekstowe wobec ,ja” twórcy), „Teksty” 1981, nr 6, s. 40. 
Stanleya Fisha. Neopragmatyzm pokazał, iż za pomocą tych samych metod można badać różne teksty jako wytwory kultury. Inspirujące mogą okazać się także analizy skupione wokół nurtu określanego jako ,prawo i literatura” (law and literature), wśród których sytuują się problemy interpretacyjne. W anglosaskich ujęciach są one od dawna obecne w zgłębianiu specyfiki językowej strony prawa. Można oczywiście upatrywać źródeł ich popularności w specyfice anglosaskich systemów prawnych i utrwalonego tam modelu orzecznictwa. To, co z punktu widzenia teoretycznoprawnych analiz jest (jak się wydaje) najbardziej inspirujące, to nie tyle badania prowadzone $\mathrm{w}$ zakresie nurtów law in literature czy law as literature, ile wykorzystanie pewnych zabiegów metodologicznych, umożliwiających analizę problemów tekstu prawnego z użyciem narzędzi i metod stosowanych przez teorię literatury. Dokonania nurtu „prawo i literatura” mogą zostać wykorzystane do analizy problemów interpretacyjnych tekstu prawnego badanego w zestawieniu z tekstem literackim.

Możliwość użycia w prawoznawstwie przywołanych wyżej koncepcji jest $\mathrm{w}$ tym miejscu jedynie sygnalizowana, a w przyszłości wymagałaby głębszej analizy. Warto jednak spostrzec, że zasięg integracji dyscyplin ulega przekształceniom w wyniku zmian zachodzących w całej humanistyce.

\section{Interpretacyjny esencjalizm versus egzystencjalizm}

Zauważalne jest, iż kwestie integracji dyscyplin nabierają szczególnego znaczenia w świetle przemian zachodzących w rzeczywistości społecznej i naukach humanistycznych. Chodzi tu w szczególności o wpływ na interpretację kontekstu kulturowego, co oczywiście jest następstwem przekonania, że tekst prawny, tak jak inne wytwory myśli ludzkiej, stanowi element kultury. Tak rozumiana interpretacja jest uwarunkowana kulturowo, jej wyznacznikiem jest cel. Warto zauważyć, że w wielu przypadkach decyzje interpretacyjne, zwłaszcza te najbardziej skomplikowane, są zbieżne z potrzebą dokonywania wyborów aksjologicznych. Interpretator dokonuje analizy treści zarówno pod względem językowym, jak i poprzez odniesienie do danych wartości, wykorzystując - jak pisze Artur Kozak - „kulturowy i «przed-językowy» charakter wartości”. Można uznać, że spór o znaczenie nie mieści się więc w kryteriach językowych, lecz kontekstowych. Traktowanie języka (także prawa) jako obiektu kulturowego uniemożliwia oderwanie znaczenia od wyznaczników kulturowych ${ }^{10}$, a zatem pozajęzykowych, a nie tylko językowych. Rozumienie wypowiedzi wynika nie tylko z prawidłowej analizy jej strukturalnych składników, lecz także z prawidłowego jej odniesienia do „świata zewnętrznego" ${ }^{11}$. To może komplikować kwestie

\footnotetext{
9 A. Kozak, op. cit., s. 42.

${ }^{10}$ Ibidem, s. 32 i n.

11 Ibidem, s. 39.
} 
oddzielenia tekstu od kontekstu. Przekonanie takie znajdziemy np. w poglądach Stanleya Fisha, według którego: „zdanie [...] nigdy nie występuje w oderwaniu od kontekstu; zawsze pojawia się w jakiejś sytuacji i sytuacja ta z góry określi cele, dla jakich może być ono użyte [...], zawsze ma znaczenie wymuszone w nim przez sytuację, w której jest wypowiedziane" ${ }^{\prime 2}$. Znaczenia są w taki, a nie inny sposób rozumiane ze względu na społeczne uwarunkowania języka. Nie jest to raz ustalona, algorytmiczna struktura; zmienia się ona wraz z przyjętymi praktykami i celami interpretacji ${ }^{13}$. Nie będzie to zatem ani jedynie „bezpośrednie rozumienie”, jak powiedziałby Jerzy Wróblewski, ani „znaczenie oczywiste, dosłowne" w ujęciu Fisha. Znaczenie jest kreowane w ramach wspólnoty komunikacyjnej i interpretacyjnej podczas ciągłej reinterpretacji tekstu w świetle kontekstu interpretacji. Prawo jest bowiem poddawane interpretacji w ramach wspólnoty komunikacyjnej. Warunkiem komunikacji w tej wspólnocie jest dysponowanie niezbędną kompetencją do rekonstruowania sensów symbolicznych. Umiejętność interpretacji tekstu zakorzenionego w kulturowym kontekście wymaga odpowiedniej kompetencji, która jest nabywana za pomocą różnorakich doświadczeń, wiedzy i wrażliwości ${ }^{14}$.

Źródłem ustalania znaczenia pojęć nie jest sam język (jako system w sensie lingwistycznym), ale szeroko pojęty kontekst kulturowy i sytuacyjny. Należy dodać, iż nie chodzi tutaj o kontekst językowy czy społeczno-polityczny, dobrze znany w teorii prawa i zdefiniowany wiele lat temu przez Jerzego Wróblewskiego ${ }^{15}$, lecz o sytuację ustalania znaczenia uwzględniającego hermeneutyczne nastawienie do rozumienia. Chodzi o takie pojmowanie kontekstu, które wynika z przyjęcia założeń twórczego podejścia do interpretacji, co jest następstwem zwrotu kulturowego w humanistyce. Tworzą ten kontekst pozajęzykowe uwarunkowania znaczenia, stanowiące konsekwencję postrzegania tekstu jako obiektu kulturowego, ergo jest to sytuacyjny kontekst interpretacji w szerokim rozumieniu ${ }^{16}$. Będą się w nim zawierały wyznaczniki „pre-rozumienia” czy Fishowski „zestaw

${ }^{12} \mathrm{~S}$. Fish, Zwykte okoliczności, język dosłowny, bezpośrednie akty mowy, to, co normalne, potoczne, oczywiste, zrozumiałe samo przez się i inne szczególne przypadki, [w:] idem, Interpretacja, retoryka, polityka. Eseje wybrane, red. A. Szahaj, Kraków 2002, s. 57.

${ }^{13}$ S. Fish, Czy na tych ćwiczeniach jest tekst?, [w:] idem, Interpretacja, retoryka, polityka..., s. 76-77.

${ }^{14}$ B. Tokarz, Lingwistyczne korzenie poetyki w perspektywie kulturowej teorii literatury, [w:] M. Cyzman, A. Skubaczewska-Pniewska (red.), Teoria literatury w świetle językoznawstwa, Toruń 2011, s. 124.

${ }^{15}$ Jerzy Wróblewski definiując społeczno-polityczny kontekst interpretacji, wyodrębnia w nim przede wszystkim cel wykładni oraz rolę ocen i reguł społecznych - J. Wróblewski, Zagadnienia teorii wyktadni prawa ludowego, Warszawa 1959, s. 353 i n.

${ }^{16}$ Por. M. Andruszkiewicz, O kontekście interpretacyjnym $w$ języku prawnym ( $w$ świetle koncepcji Stanleya Fisha), [w:] A. Jamróz, S. Bożyk (red.), Konstytucja, ustrój polityczny, system organów państwowych. Prace ofiarowane Profesorowi Marianowi Grzybowskiemu, Białystok 2010, s. 23-38. 
przesądzeń"17 wpływających na interpretację. Takie podejście jest, oczywiście, konsekwencją pokartezjańskich przemian, związanych ze zrewidowaniem przekonania o pierwotnym charakterze myślenia wobec bytu. W uproszczeniu można określić je jako przeformułowanie cogito ergo sum w pewnego rodzaju egzystencjalizm (wyrażony w sum ergo cogito). Znajdujemy to chociażby w antyesencjalistycznym nastawieniu do interpretacji Stanleya Fisha, który uważa interpretację za problem empiryczny, a nie teoretyczny ${ }^{18}$.

Zauważalne jest, iż zmiany zachodzące w kulturze, humanistyce i w pojmowaniu prawa znajdują odzwierciedlenie w ewoluowaniu tendencji integracyjnych między prawoznawstwem a dyscyplinami badającymi język, czy w ogóle między dyscyplinami. Pojmowanie zakresu integracji daje się przedstawić jako konsekwencja określonego sposobu pojmowania prawa. Można stwierdzić, iż dalece uproszczone ukazanie sporu o istotę prawa jako kontrowersji ontologicznych rozmieszczonych między nominalizmem, konceptualizmem a realizmem spowoduje, że problem języka prawa i jego interpretacji będzie polegać na odróżnieniu, czy jest to byt, obiekt mentalny, czy też pewien zbiór powinności. Pytanie o to, czym jest język prawny, może być pytaniem o to, czym jest samo prawo. I odwrotnie. Rozstrzygnięcia natury ontologicznej wpływają na możliwość akceptacji takich, a nie innych metod interdyscyplinarnych. Jeśli ewolucję związków prawoznawstwa $\mathrm{z}$ dyscyplinami badającymi język przedstawimy w dwubiegunowym zestawieniu - od języków formalnych do nurtu law and literature - to można powiedzieć, że jest ona ukierunkowana od koncepcji podejmujących badania struktur językowych, poszukiwania czy oczekiwania jednoznaczności w tekście prawnym do interpretacjonizmu i kontekstualizmu. Wśród pierwszych odnajdziemy nawiązania do filozofii analitycznej, rekonstrukcjonizmu, formalizmu, atomizmu logicznego Wittgensteina z pierwszego etapu twórczości, gramatyk formalnych Chomsky'ego. Z kolei drugi biegun tych nawiązań będzie odpowiadał założeniom, że język jest złożoną aktywnością, gdzie sytuuje się pluralizm językowy Wittgensteina, kontekstualizm, dyskursywne podejście do analizy prawa, koncepcje otwartej tekstowości Harta czy ujęcia interpretacji proponowane przez Fisha. $Z$ jednej strony będzie to integracja w nawiązaniu do strukturalizmu i formalizmu, zakładających, iż struktura jest przed podmiotem i kontekstem oraz przyjmujących dogmatyzm interpretacyjny. $Z$ drugiej natomiast można umieścić koncepcje uznające, że język jest tworem zmieniającym się, kontekstowym, a znaczenia i interpretacje są zmienne. Mieszczą się tutaj fenomenologia, hermeneutyka czy poststrukturalizm, w wyniku zwrotu kulturowego dające pierwszeństwo kontekstowi przed systemem, struktura. Jednocześnie towarzyszą temu, z jednej strony, przekonanie, że tekst jest autonomicznym obiektem (formalizm,

${ }^{17}$ A. Szahaj, Zniewalajaca moc kultury. Przedmowa, [w:] S. Fish, Interpretacja, retoryka, polityka..., s. 15.

${ }^{18}$ S. Fish, Profesjonalna poprawność..., s. 9. 
strukturalizm, teoria aktów mowy), z drugiej natomiast ujęcia tekstu jako nieautonomicznego (poststrukturalizm, teoria rezonansu czytelniczego, intertekstualizm). Nawiasem mówiąc, przeniesienie tej ewolucji na grunt prawoznawstwa pozwala dostrzec, z jednej strony, ujęcie formalistyczne, pozytywistyczne, $\mathrm{z}$ drugiej natomiast przeciwstawiane mu niepozytwistyczne podejście do prawa. Traktowanie tekstu jako obiektu kulturowego stwarza możliwość wpisania się w tradycję interpretacji literackiej, która - tak jak interpretacja prawnicza - ma swoje korzenie w interpretacji humanistycznej i historycznie pojmowanej hermeneutyce, akcentującej dyskursywne postrzeganie interpretacji. Hermeneutyczne ujęcie znaczenia i rozumienia wymaga też zrewidowania przekonania, że tekst jest możliwy do zrozumienia bez uruchamiania zabiegów interpretacyjnych. Na płaszczyźnie teorii prawa konsekwencją takiej postawy może być odchodzenie od zasady clara non sunt interpretanda na rzecz omnia sunt interpretanda ${ }^{19}$.

\section{Transdyscyplinarne perspektywy integracji}

Analiza interdyscyplinarnych metod stosowanych przez teoretyków prawa przekonuje, że do eksplorowania kwestii interpretacji tekstu prawnego, zwłaszcza w kontekście ponowoczesnej ekspansji interpretacjonizmu i kontekstualizmu, bardziej produktywne niż językoznawcze czy pochodzące z nauk dedukcyjnych mogą okazać się narzędzia teoretycznoliterackie. Jak się wydaje, następuje modyfikacja i poszerzanie się zakresu integracji zewnętrznej prawoznawstwa w związ$\mathrm{ku} \mathrm{z}$ relacjami transdyscyplinarnymi między dziedzinami, co jest uzasadnione ponowoczesnym pluralizmem naukowych dyskursów. Wydaje się, iż w zakresie integracji zewnętrznej prawoznawstwa nie są to badania stricte „międzydyscyplinarne”, a właśnie „transdyscyplinarne”. Przedmiot badania prawoznawstwa i nauk o języku stanowią całkowicie odmienne obiekty, jednakże dają się zaobserwować pewne pokrewieństwa w możliwości ich analizy. Pojęcie relacji „transdyscyplinarnych" jest inspirowane ujęciem Michała P. Markowskiego, zdaniem którego takie związki uwzględniają zarówno powinowactwa dyscyplin już istniejących, jak i tworzenie się nowych, a także stopniową rekonfigurację dyscyplinowych podziałów całej humanistyki ${ }^{20}$. W kontekście poststrukturalistycznych tendencji przenikania się dyscyplin humanistycznych, współistnienia wielu dyskursów, integracja powoduje zacieranie się wyraźnych granic między nimi. Są to relacje nie inter-, ale - jak pisze Markowski - idące w poprzek (poniżej, powyżej) istniejących granic dyscyplinowych. Należy zauważyć, że dotyczy to również innych niż

${ }^{19}$ M. Zieliński, M. Zirk-Sadowski, Klaryfikacyjność i derywacyjność w integrowaniu polskich teorii wyktadni prawa, „Ruch Prawniczy, Ekonomiczny i Socjologiczny” 2011, z. 2, s. 110.

${ }^{20}$ M. P. Markowski, Kulturowa natura, staby profesjonalizm. Kilka uwag o przedmiocie poznania literackiego i statusie dyskursu literaturoznawczego, [w:] M. P. Markowski, R. Nycz (red.), Kulturowa teoria literatury. Główne pojęcia i problemy, Kraków 2006, s. 30. 
prawoznawstwo dziedzin humanistycznych. W językoznawstwie następuje odchodzenie od analizy strukturalnej i otwieranie się na inne nauki społeczne w związku z przełomem, jaki miał miejsce po odkryciu pragmalingwistyki oraz badania języka nie jako struktury, ale części kontekstu, o czym świadczy ewoluowanie od koncepcji najmniejszych jednostek języka na rzecz większych całości. Znajduje to wyraz w globalnej analizie znaczenia tekstu poprzez odniesienie do kontekstu np. mitów czy przypowieści² ${ }^{21}$ Efektem takich związków jest też kształtowanie się nurtów i koncepcji integrujących różne nauki w ramach nauk kognitywnych (jak neurokognitywistyka, psycholingwistyka, nauki o komunikowaniu). Podobnie w literaturoznawstwie - pytanie o sens tekstu staje się pytaniem zakorzenionym w kontekście uwarunkowań kulturowych, politycznych, etycznych ${ }^{22}$. Konsekwencją tego są badania kulturowe prowadzone w ramach np. poetyki kulturowej czy kulturowej teorii literatury. Otwieranie się granic nauk humanistycznych jest faktem uzasadnianym przez istnienie wspólnych kulturowych uwarunkowań literatury, polityki czy prawa. Poststrukturalistyczny pluralizm dyskursów antycypuje prawdopodobieństwo współistnienia i harmonizacji różnych dyscyplin, co można zobrazować za pomocą (nawiązującej do monadologii Leibniza) metafory ,jedności w wielości”, sformułowanej w Witkacowskiej koncepcji filozoficznej ${ }^{23}$.

Należy również wspomnieć o podnoszonych w literaturze argumentach krytycznych wobec integracji dyscyplin oraz kontrowersjach związanych z typowym dla ponowoczesności swoistym metodologicznym anarchizmem ${ }^{24}$. W kontekście transdyscyplinarnych relacji między naukami istotna jest zarówno ich wzajemna korespondencja, jak i zaznaczenie odrębności. Poststrukturalistyczny pluralizm dyskursów, zróżnicowanie koncepcji znaczenia, interpretacji prawniczej czy samego pojęcia prawa nie musi oznaczać braku porozumienia między przedstawicielami różnych dyscyplin. Może natomiast stanowić punkt wyjścia do zrekonstruowania oczekiwanych celów funkcjonowania prawa w społecznej rzeczywistości we wspólnej kulturowej przestrzeni komunikacji. Mogłoby to przejawiać się w uzgodnionych założeniach jego twórców, interpretatorów i podmiotów orzekających, dotyczących nie tyle jednoznaczności reguł języka, ile sensowności, słuszności rozstrzygnięć prawnych czy interpretacyjnych, z uwzględnieniem wyznaczników kulturowych, kontekstowych i aksjologicznych.

${ }^{21}$ S. Gajda, Znaczenie w stylistyce, wystąpienie podczas Konferencji Naukowej „Znaczenie i Styl”, organizowanej przez Komisję Stylistyczną Komitetu Językoznawstwa PAN i Instytut Filologii Polskiej Uniwersytetu w Białymstoku, Białystok, 20-21 września 2007 r.

${ }^{22}$ B. Tokarz, op. cit., s. 120.

${ }^{23}$ Zob. np. S. I. Witkiewicz, Pojęcia i twierdzenia implikowane przez pojęcie istnienia i inne pisma filozoficzne, Warszawa 2002, s. 160 i n.

${ }^{24}$ Do badaczy prezentujących sceptyczny stosunek do takiej unifikacji czy idei interdyscyplinarności integrujących dyscypliny humanistyczne w ramach wspólnych badań kulturowych zalicza się m.in. Stanley Fish. Jego zdaniem mogłyby one stanowić zagrożenie dla wewnętrznej inteligibilności nauk i powodować ich dezintegrację - S. Fish, Profesjonalna poprawność..., s. 74. 
Nie jest, rzecz jasna, możliwe rozstrzygnięcie czy też wyczerpujące uzasadnienie ledwie zarysowanych powyżej kwestii i dylematów. Wymagałoby to znacznie bardziej pogłębionych studiów, wykraczających poza ramy tego niewielkiego tekstu. Wydaje się, iż pytanie o przyszłość czy perspektywy integracji zewnętrznej prawoznawstwa pozostaje otwarte. $Z$ jednej strony można powiedzieć, że produktywne jest wykorzystywanie pokrewieństwa dyscyplin, z drugiej natomiast ważne jest też zachowanie autonomiczności i niezatracanie ich inteligibilności. W poglądach Jerzego Wróblewskiego na temat wielopłaszczyznowości metodologicznej prawoznawstwa znajdujemy przekonanie, iż stosowanie różnych metod do badania prawa uzasadnione jest różnymi potrzebami analizy oraz różnorodnością problemów, a metody te nie muszą być konkurencyjne, lecz mogą się nawzajem uzupełniać ${ }^{25}$. Jeżeli nie będzie to nadmiernym relatywizowaniem, wypada stwierdzić, iż odpowiedź na pytanie o zakres integracji może zależeć od tego, za jaką opowiemy się koncepcją prawa, języka i interpretacji.

${ }^{25}$ J. Wróblewski, Filozoficzno-metodologiczne zagadnienia współczesnej amerykańskiej teorii prawa, „Studia Prawno-Ekonomiczne” 1983, t. XXX, s. 28, 35-36. 